\title{
Study of the Qualitative Characteristics of Rapeseed Oil Obtained by Cold Pressing
}

\section{Natalia L Kleymenova, Inessa N Bolgova, Maxim V Kopylov, and Ekaterina Y Zheltoukhova}

FSBEI HE "Voronezh State University of Engineering Technologies" (FSBEI HE "VSUET"), 19 Revolution Ave., Voronezh, 394036, Russia

ORCID:

Natalia L Kleymenova: http://orcid.org/0000-0002-1462-4055

\section{Abstract}

Oil from spring rape seeds obtained by cold pressing was selected as the object of this study. Oil samples were obtained under the following technological conditions: the annular gap was $0.7 \mathrm{~mm}$ in a grain chamber and the screw rotation speed was $160 \mathrm{rpm}$ at a pressing temperature of $315 \mathrm{~K}$. The oil composition was studied by gas-liquid chromatography on the Chromotech 5000 apparatus. Rapeseed oil characteristics were obtained with chromatograms. An increased content of linoleic

Corresponding Author: Natalia L Kleymenova klesha78@list.ru

Published: 5 April 2021

Publishing services provided by Knowledge E

(c) Natalia L Kleymenova et al. This article is distributed under the terms of the commons Attribution License, which permits unrestricted use and redistribution provided that the original author and source are credited.

Selection and Peer-review under the responsibility of the DonAgro Conference Committee.

\section{G OPEN ACCESS} acid $20 \%(\omega 6)$ and linolenic acid $12 \%(\omega 3)$ was revealed in the fatty acid composition of the sample. Fatty acids contribute to lipid metabolism regulation. They are of primary importance in the diet. The presence of $58.6 \%$ oleic acid ( $\omega 9)$ was identified. The resulting rapeseed oil had healing properties due to the presence of $\omega 3, \omega 6$ and $\omega 9$. Vitamin $B$, vitamin $K$, traces of vitamin $A$, and $\alpha, \beta+\gamma, \delta$-tocopherols were found. $\alpha, \beta+\gamma$-tocopherols contribute to the oxidation process. According to these results, rapeseed oil can be confidently recommended for introduction into various food recipes.

Keywords: rapeseed oil, vitamins, fatty acid composition.

\section{Introduction}

Modern population consumes a large amount of refined foods, so there is a deficiency in various nutrients. A promising direction in food production is the creation of new functional foods from unconventional raw materials containing biologically active components (proteins, lipids, vitamins, etc.) necessary for humans [1].

Nowadays the use of rapeseed as an oilseed is relevant due to its high profitability. That is why there is an increased demand for them [2] now. According to this demand, rapeseeds occupy the second place in the Russian Federation. Rapeseed oil is used in the chemical, food and textile industries. Rapeseed oil has been used relatively recently for the food purposes. The reason for this is the use of modern clarification methods, 
improving the quality of rapeseeds, breeding of hybrid varieties with a high content of linolenic acid and a low content of erucic acid.

With the introduction of innovations in the oil industry, it makes sense to process rapeseeds by cold pressing to produce the oil with biologically active substances, and to use the resulting oil for blending [3].

One of the advantages of rapeseed oil is its transparency and the absence of a change in taste during oxidation [4]. In rape seeds, the content of valuable fats and proteins reaches $31 \%$. Compared to other types of oils, rapeseed oil contains the optimal amount of fatty acids [5]. However, there is a drawback - erucic acid and thioglysides, which negatively affect the body, are present in it. The amount of monounsaturated acids is about $65 \%[6,7]$.

Rapeseed oil contains a large amount of vitamins: $\mathrm{E}$ up to $120 \%$ and $\mathrm{K}$ up to $60 \%$. Vitamins play a special role in the nutrition and support of human health. With their insufficient consumption, life expectancy, ability to work, and resistance to diseases are reduced. The aim of the study is to determine the fatty acid and vitamin composition of rapeseed oil to further predict the optimal properties of future blends.

\section{Methods and Equipment}

\subsection{Methods}

The oil obtained from spring rapeseeds was studied in the work. According to literature data, it is known that fatty acids of the $\omega 3, \omega 6, \omega 9$ group are part of rapeseed oil. They are presented in Table 1.

An analysis of literature data showed that the composition of rapeseed oil is represented by saturated fatty acid - palmitic, therefore, the oil contains tripalmitin in the glyceride composition [10]. A significant content of polyunsaturated fatty acid - oleic contributes to a decrease in storage stability.

Rapeseeds cold pressing was carried out in the experimental unit with an annular grain chamber gap of $0.7 \mathrm{~mm}$, a screw rotation speed of $160 \mathrm{rpm}$, and a pressing temperature of $315 \mathrm{~K}$.

The fatty acid composition of rapeseed oil was determined with gas-liquid chromatography according to GOST 31665-2012 "Vegetable oils and animal fats. Obtaining of fatty acids methyl esters", GOST 31663 - 2012 "Vegetable oils and animal fats. Determination of the mass fraction of fatty acids methyl esters by gas chromatography." The SP-2560 column, as well as the Chromotech 5000 gas chromatograph, were used in the work. 
TABLE 1: The fatty acid content of rapeseed oil.

\begin{tabular}{|c|c|c|c|c|}
\hline $\begin{array}{l}\text { Name of fatty } \\
\text { acids }\end{array}$ & $\begin{array}{l}\text { Literature data,\% } \\
\text { of total fatty acids } \\
\text { [8] }\end{array}$ & $\begin{array}{c}\text { Literature data,\% } \\
\text { of total fatty acids } \\
\text { [9] }\end{array}$ & $\begin{array}{c}\text { Literature data,\% } \\
\text { of total fatty acids } \\
{[10]}\end{array}$ & $\begin{array}{c}\text { Literature data,\% } \\
\text { of total fatty acids } \\
\text { [11] }\end{array}$ \\
\hline C12:0 Lauric & - & 0.02 & - & \\
\hline C14:0 Myristinic & - & 0.09 & - & \\
\hline $\begin{array}{l}\text { C15:0 } \\
\text { Pentadecanoic }\end{array}$ & - & 0.02 & - & \\
\hline $\begin{array}{l}\text { C15:1 } \\
\text { Pentadecenic }\end{array}$ & - & 0.01 & - & \\
\hline C16:0 Palmitic & - & 4.52 & 4.0 & $2.7-3.7$ \\
\hline $\begin{array}{l}\text { C16:1 } \\
\text { Hexadecenoic }\end{array}$ & - & 0.06 & - & \\
\hline $\begin{array}{l}\text { C16:1, 9-cis } \\
\text { Palmitoleic }\end{array}$ & - & 0.29 & - & \\
\hline $\begin{array}{l}\text { C16:2 } \\
\text { Hexadecadienoic }\end{array}$ & - & 0.02 & - & \\
\hline C17:0 Margaric & - & 0.04 & - & \\
\hline $\begin{array}{l}\text { C17:1 } \\
\text { Heptadecenoic }\end{array}$ & - & 0.03 & - & \\
\hline C18:0 Stearic & 12.4 & 1.73 & 50 & $0.9-2.3$ \\
\hline C18:1, 9-cis Oleic & 0.54 & 57.24 & 5 & $75.1-82.3$ \\
\hline $\begin{array}{l}\text { C18:1, 11-trans } \\
\text { Vaccenic }\end{array}$ & - & 3.02 & - & \\
\hline C18:2 Linoleic & 72.84 & 20.58 & - & $6.9-12.7$ \\
\hline C18:3 Linolenic & 0.22 & - & - & 2.3-6.5 \\
\hline C20:0 Arachic & - & 0.49 & - & \\
\hline C20:1 Gondoinic & 3.37 & 1.21 & - & \\
\hline $\begin{array}{l}\text { C20:2 } \\
\text { Eicosadienoic }\end{array}$ & - & 0.16 & - & \\
\hline $\begin{array}{l}\text { C20:3 } \\
\text { Eicosatrienoic }\end{array}$ & - & 0.06 & - & \\
\hline C22:0 Behenic & 1.74 & 0.20 & - & \\
\hline C22:1 Erucic & 1.06 & 0.61 & 1 & up to 0.1 \\
\hline $\begin{array}{l}\text { C22:2 } \\
\text { Docosadienoic }\end{array}$ & - & 0.03 & - & \\
\hline $\begin{array}{l}\text { C22:3 } \\
\text { Docosatrienoic }\end{array}$ & - & 0.11 & - & \\
\hline C23:0 Tricosanoic & 0.86 & - & - & \\
\hline C24:0 Lignoceric & 0.42 & 0.06 & - & \\
\hline
\end{tabular}

The main objective was to study the fatty acid and vitamin composition of rapeseed oil by gas-liquid chromatography to further evaluation of the safety and prospects of its use in food. 
TABLE 2: Rapeseed oil components calculation results.

\begin{tabular}{|c|c|c|c|c|c|}
\hline Component & Time, $\min$ & Area, $\mathrm{mV} \cdot \mathrm{s}$ & Area, \% & $\begin{array}{l}\text { Response } \\
\text { factor }\end{array}$ & $\begin{array}{c}\text { Concentration, } \\
\%\end{array}$ \\
\hline C4:0 Oleic & 8.958 & 2.953 & 0.014 & 1.428 & 0.020 \\
\hline C6:0 Caproic & 9.496 & 1.281 & 0.006 & 1.237 & 0.007 \\
\hline C8:0 Caprylic & 10.520 & 1.193 & 0.006 & 1.114 & 0.006 \\
\hline C10:0 Capric & 12.375 & 4.972 & 0.023 & 1.041 & 0.024 \\
\hline C12:0 Lauric & 15.441 & 8.612 & 0.041 & 1.061 & 0.041 \\
\hline C14:0 Myristic & 19.856 & 30.532 & 0.144 & 0.997 & 0.141 \\
\hline C15:0 Pentadecanoic & 22.492 & 5.592 & 0.026 & 1.007 & 0.026 \\
\hline C16:0 Palmitic & 25.371 & 961.683 & 4.525 & 1.000 & 4.453 \\
\hline C16:1 Palmitoleic & 27.241 & 47.545 & 0.224 & 0.997 & 0.219 \\
\hline C17:0 Margaric & 28.322 & 9.857 & 0.046 & 1.009 & 0.046 \\
\hline C18:0 Stearic & 31.667 & 387.497 & 1.823 & 1.005 & 1.803 \\
\hline C18:1n9c Oleic & 33.972 & 12696.692 & 59.738 & 0.997 & 58.612 \\
\hline C18:2n6c Linoleic & 37.282 & 4201.546 & 19.768 & 1.011 & 19.668 \\
\hline C20:0 Arachic & 39.771 & 130.353 & 0.613 & 0.981 & 0.592 \\
\hline $\begin{array}{l}\text { C18:3c9 } \alpha \text {-Linolenic } \\
\text { Alfa-Linolenic }\end{array}$ & 41.879 & 2171.534 & 10.217 & 1.149 & 11.553 \\
\hline C20:1 Eicosenic & 42.553 & 330.488 & 1.555 & 0.991 & 1.516 \\
\hline C21:1 Uncosanoic & 44.605 & 3.075 & 0.014 & 1.023 & 0.015 \\
\hline C20:2 Eicosadienoic & 46.365 & 19.501 & 0.092 & 1.091 & 0.099 \\
\hline C22:0 Behenic & 48.489 & 74.547 & 0.351 & 0.986 & 0.340 \\
\hline $\begin{array}{l}\text { C20:3n11C } \\
\text { Eicosatrienoic }\end{array}$ & 49.945 & 4.004 & 0.019 & 1.074 & 0.020 \\
\hline C22:1 Erucic & 50.372 & 76.662 & 0.361 & 1.122 & 0.398 \\
\hline $\begin{array}{l}\text { C20:5 } \\
\text { Eicosapentaenoic }\end{array}$ & 53.587 & 11.303 & 0.053 & 1.114 & 0.058 \\
\hline C24:0 Lignoceric & 54.703 & 32.987 & 0.155 & 1.030 & 0.157 \\
\hline $\begin{array}{l}\text { C24:1 Selacholeic } \\
\text { (Nervonic) }\end{array}$ & 56.454 & 39.403 & 0.185 & 1.015 & 0.185 \\
\hline
\end{tabular}

\section{Results}

Peaks for the chromatogram of the oil sample tested were determined with the normalization method. The qualitative characteristics of its components were determined by area. The results of the qualitative characteristics of the test sample in the fatty acids composition are presented in Table 2.

As we can see from Table 2 and Figure 1, not all the results obtained correlate with literature data. The composition of rapeseed oil obtained by cold pressing, practically does not contain erucic acid. The presence of oleic acid in rapeseed oil is $58.6 \%$, which allows it to be attributed to high-quality edible oils. 
PID-1

Interval from 0.000 minutes to 72.471 minutes

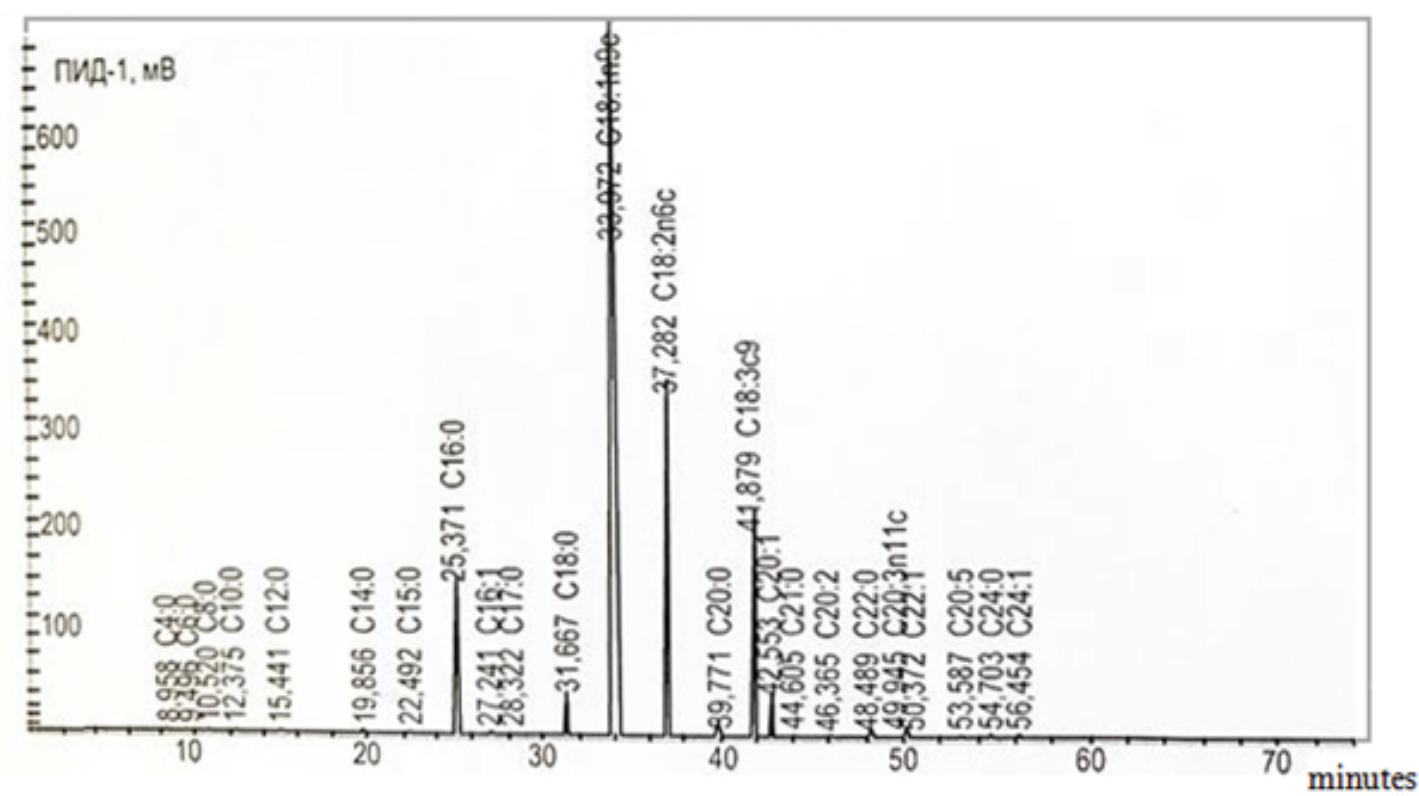

Figure 1: Chromatogram of rapeseed oil fatty acids content.

A comparative analysis of the fatty acid composition of rapeseed oil with standard values is presented in Figure 2 a, b [12, 13].
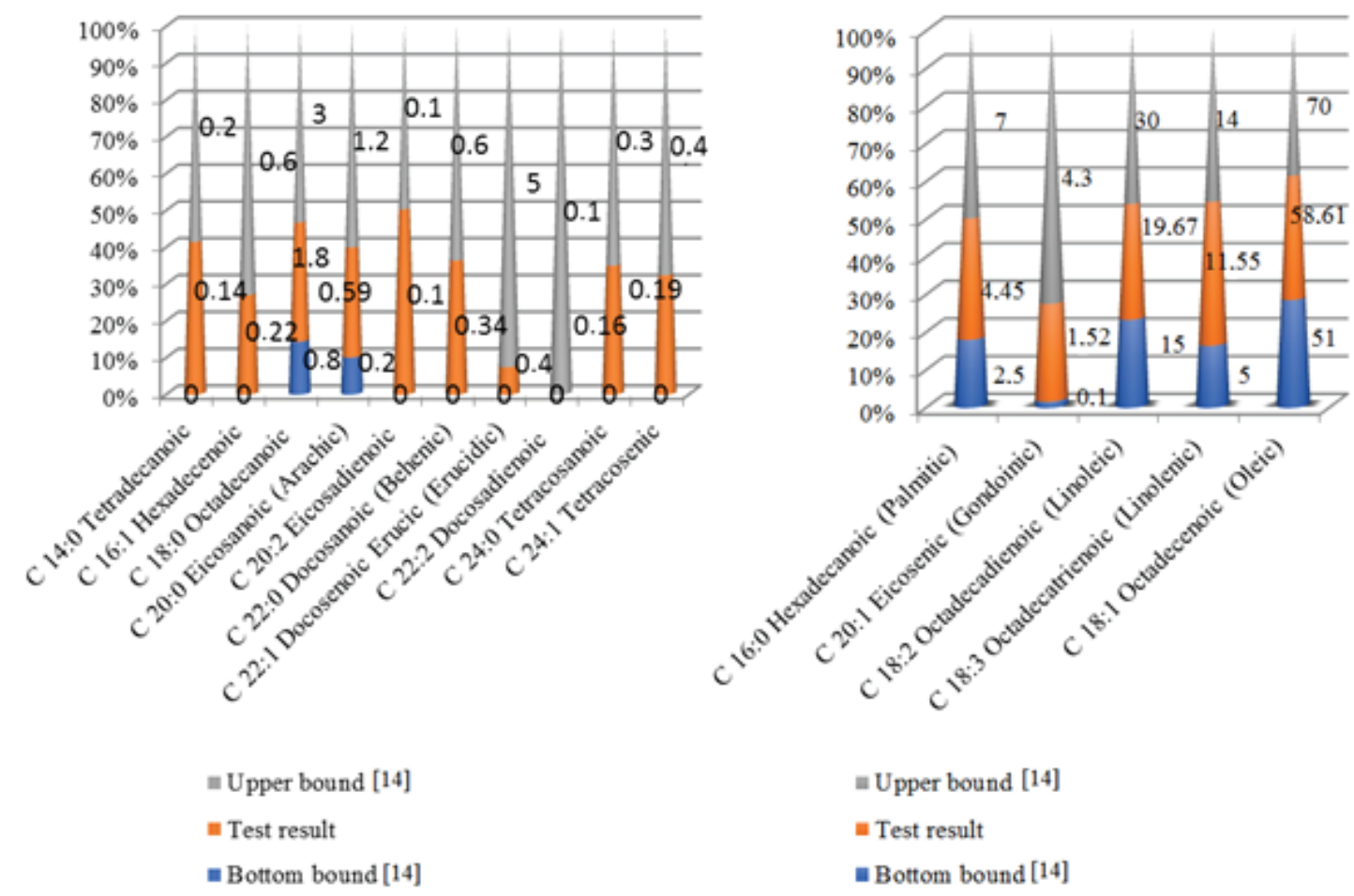

Figure 2: The results of studies of rapeseed oil fatty acid composition: with a fatty acid content limit of up to 3 (a); with an acid content limit of up to 70 (b). 
GOST 30417-96 "Vegetable oils. Methods for determining the mass fractions of vitamins A and E" [14] was used to determine the vitamin composition of rapeseed oil. The results of the analysis are presented in Figure 3.

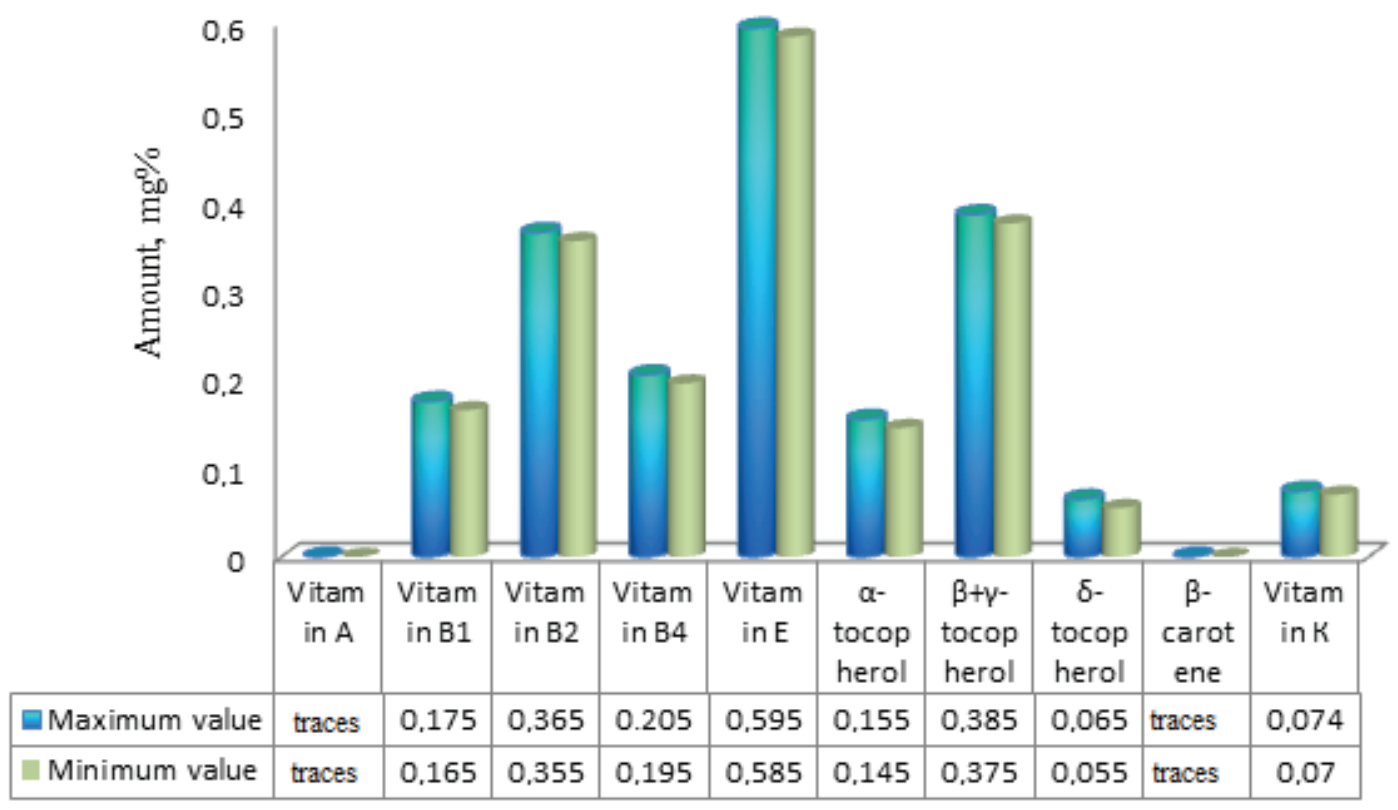

Figure 3: The results of chemical composition in the sample tested.

\section{Discussion}

According to the research results, the fatty acid composition of the rapeseed oil sample contains an increased content of linoleic acid of $20 \%(\omega 6)$ and linolenic acid of $12 \%(\omega 3)$. However, according to the literature data it was revealed that for oil from spring rape the amount of $\omega 6$ is $5-5.5 \%$ and $\omega 3$ is $4.5-6 \%$, respectively [15]. Analysis of rapeseed oil composition proved that it contains saturated fatty acid (palmitic) in an amount of $4.4 \%$, as well as monounsaturated fatty acid $\omega 9$ and polyunsaturated fatty acids of the $\omega 6$ and $\omega 3$ series. Oleic acid ( $\omega 9)$ is necessary for lipid metabolism, and it is also an antioxidant $[16,17]$. Thus, the results obtained are in the range not exceeding the normative values of GOST 31759-2012 «Rapeseed oil. Technical conditions" [18].

The amount of erucic acid in the test oil is $0.4 \%$. The increased content of polyunsaturated fatty acids in the sample confirms the studies of scientists [19] that these acids participate in the construction of cell membranes, help to synthesize hormones, regulate metabolism in cells and remove cholesterol, and reduce diseases of the cardiovascular and nervous system. Analysis of the fatty acid composition of rapeseed oil complies with international standards [20]. 
The analysis of Figure 3 showed that the test sample contains a rational ratio of saturated and polyunsaturated acids. The discovered $B$ vitamins help to strengthen the nervous system. The present vitamin $E$ has antioxidant properties and is recommended for daily use with food. The rational content of $\alpha$-tocopherol helps to slow down or prevent oxidation. The presence of $\beta+\gamma$-tocopherols in rapeseed oil will ensure oxidation stability, and $\beta+\gamma$-tocopherols will also act as antioxidants.

Rapeseed oil has a grassy odor that does not satisfy consumers, so itis necessary to carry out some studies to select the taste and aroma of rapeseed oil and to develop blends with various ingredients.

\section{Conclusion}

Thus, the test sample of rapeseed oil obtained with cold pressing contains about $59 \%$ of oleic acid, which is a valuable property and allows to use this oil for diabetic nutrition, to lower cholesterol, etc. Another identified advantage of rapeseed oil is the presence of the essential fatty acids $\omega 3$ and $\omega 6$. The biological value of vitamins found in oil opens up prospects for using it as an ingredient in functional foods. The $\alpha, \beta+\gamma$ tocopherols discovered as a result of research contribute to the maintenance of the oxidation process. Analysis of the results allows us to conclude that rapeseed oil can be recommended for blending.

\section{Funding}

Self-financing.

\section{Acknowledgement}

They are also thankful to all the reviewers who gave their valuable inputs to the manuscript and helped in completing the paper.

\section{Conflict of Interest}

The authors have no conflict of interest to declare. 


\section{References}

[1] Fu, D., et al. (2016). Research Progress and Strategies for Multifunctional Rapeseed: A Case Study of China. Journal of Integrative Agriculture, vol. 15, issue 8, pp. 16731684.

[2] Khromtsev, D. F. (2013). The Possibility of Cultivating Oilseeds and Essential Oil Crops in the Ryazan Region. International Technical and Economic Journal, vol. 4, pp. 5254.

[3] Rokosik, E., Dwiecki, K. and Siger, A. (2019). The Quality of Cold-Pressed Rapeseed Oil Obtained from Seeds of Brassica Napus L. with Increased Moisture Content. Acta Scientiarum Polonorum Technologia Alimentaria, vol.18, issue 2, pp. 205-218.

[4] Vinogradov, D. V., et al. (2012). The Possibility of Expanding the Range of Oilseeds in the Southern Non-Chernozem Region. Mezhdunarodnyy tekhniko-ekonomicheskiy zhurnal, vol. 1, pp. 118-123.

[5] Beyzi, E., et al. (2019). Changes in Fatty Acid and Mineral Composition of Rapeseed (Brassica Napus Sp. Oleifera L.) Oil with Seed Sizes. Industrial Crops and Products, vol. 129, pp. 10-14.

[6] Hu, Q., et al. (2017). Rapeseed Research and Production in China. The Crop Journal, vol. 5 , issue 2 , pp. 127-135.

[7] Volovik, V. T., et al. (2019). Comparison of the Fatty Acid Composition of Various Edible Oils. International Journal of Applied and Basic Research, vol. 5, pp. 147-152.

[8] Danyliv, M. M., et al. (2015). Gas Chromatographic Analysis of the Fatty Acid Composition of Vegetable Oils as Applied to the Meat Industry. Scientific Almanac, vol. 11-3, issue 13, pp. 109-112.

[9] Renzyaeva, T. V., et al. (2018). Vegetable Oils for Preventive Dietary Nutrition. Presented at Proceedings of the International Symposium: Innovations in Food Biotechnology. 14-16 May, Kemerovo, Russia: FSBEI HE Kemerovo State University.

[10] Nikitin, V. V. and Litvinova, E. V. (2018). Rapeseed Oil as a Source of PUFA for Meat Products. Meat Technology, vol. 8, pp. 16-19.

[11] Bykova, S. F., et al. (2017). Prospects for the Development of the Raw Material Base of the Oil and Fat Complex in Russia. Food Industry, vol. 5, pp. 20-24.

[12] GOST 31759-2012 (2014). "Rapeseed oil. Technical conditions".

[13] CXS 210-1999 (2019). Standard for named vegetable oils. Adopted in 1999. Revised in 2001, 2003, 2009, 2017, 2019. Amended in 2005, 2011, 2013, 2015, 2019.

[14] GOST 30417-2018 (2018). Vegetable oils. Methods for determining the mass fractions of vitamins $\mathrm{A}$ and $\mathrm{E}$. 
[15] Lisitsyn, A. N., Bykova, S. F. and Davidenko, E. K. (2013). Prospects for the Development of the Raw Material Base for the Production of New Types of Edible Vegetable Oils. Vestnik VNIIZh, vol. 2, pp. 9-13.

[16] Chew, S. C. (2020). Cold-Pressed Rapeseed (Brassica napus) Oil. Chemistry and Functionality, vol. 131, p. 108997.

[17] Kowalski, R., et al. (2018). Effect of the Method of Rapeseed Oil Aromatisation with Rosemary Rosmarinus Officinalis L. on the Content of Volatile Fraction. LWT - Food Science and Technology, vol. 95, pp. 40-46.

[18] GOST 31759-2012 Rapeseed oil. Specifications.

[19] Mateyev, Y. Z., et al. (2019). Environmental Study of Fatty Acid Composition of Safflower Oil Received by Cold Pressing Method. EurAsian Journal of BioSciences, vol. 13, issue 1, pp. 385-391.

[20] Zhang, Y., et al. (2017). Quality of Wood-Pressed Rapeseed Oil. Journal of the American Oil Chemists' Society, vol. 94, issue 6, pp. 767-777. 